\title{
Türkiye Şeker Piyasası ve Uygulanan Politikalar*
}

\author{
Sugar Market and Policies Applied in Turkey
}

\author{
Aybüke Kaya ${ }^{1 * *}(\mathbb{D}$ \\ ${ }^{1}$ Department of Agricultural Economics, Hatay Mustafa Kemal University, Antakya, Turkey
}

\begin{abstract}
Received: 07.07.2021 Accepted: 14.12.2021
This article was checked by intihal.net

Öz

Şeker fabrikaları Türkiye’nin ilk sanayi işletmeleridir. İlk şeker fabrikaları Uşak ve Alpullu fabrikası ile Cumhuriyetin ilk yıllarında Türk şekeri üretilmeye başlanmıştır. Şeker dünyada devlet müdahalesinin en fazla uygulandığı ürünlerden biridir. Bu kapsamda uygulanan üretim kotaları, tarife kotaları, yüksek korumalar ve tercihli ticaret anlaşmaları nedeniyle dünya serbest ticareti sınırlandırılmaktadır. Bu çalışmanın amacı, kamu şeker fabrikalarının özelleştirilmesi, dünya ve Türkiye'de şeker üretimi, ticareti ve şeker piyasasındaki gelişmeleri değerlendirmektir. Şeker, dünyada en fazla şeker kamışından üretilmektedir. Bunun nedenlerinden biri de, kamış şekerinin dünyada şeker borsa fiyatlarında düşük maliyetli olmasıdır. Türkiye'de kamışüretimi yapılmadığından, şeker üretimi şeker pancarından elde edilmektedir. Dünya toplam şeker üretiminin yaklaşık \%75'ini Brezilya, Hindistan, $A B$, Çin, Tayland, ABD, Meksika, Rusya, Pakistan ve Avusturalya gibi ülkeler gerçekleştirmektedir. Türkiye'nin şeker pancarı üretimi 20 milyon tonun üzerindedir. Bu çalışmada, Türkiye'de şeker üretimi ve piyasası, sektöre yönelik uygulanan politikalara yönelik çalışmalar ortaya konulmaktadır. Bu kapsamda şeker sektörünün tarihsel gelişimi, şeker piyasasındaki gelişmeler, dış ticareti ve sektörün dünyadaki mevcut durumu incelenmiştir.
\end{abstract}

Anahtar kelimeler: Şeker, Pazarlama, Özelleştirme, Kota, Politika

\section{Abstract}

Sugar factories are the first industrial enterprises of Turkey. The first sugar factories are Uşak and Alpullu factories. Turkish sugar started to be produced in the first years of the Republic. Sugar is one of the products where government intervention is applied the most in the world. World free trade is restricted due to the applied production quotas, tariff quotas, high protections and trade agreements. The aim of this study is the privatization of public sugar factories, which are not on the agenda. To present the developments in sugar production, trade and sugar market in the world and Turkey. Sugar is produced mostly from sugar cane in the world. Low cost cane sugar dominates the world sugar stock market prices. However, cane is not produced in Turkey, it is obtained from sugar beet. Turkey's sugar beet production is over 20 million tons. In this study, sugar production and market in Turkey, privatization of sugar factories were investigated. Sugar market regarding the implemented policies have also been presented. In the study, the historical development of the sugar sector and the current situation of the sector in the world were examined. In addition, it has been evaluated with the developments in the sugar market and its foreign trade.

Keywords: Sugar, Market, Privatization, Quota, Policy

\begin{tabular}{l}
$\begin{array}{l}\text { Kaya, A. (2021). Türkiye Şeker Piyasası ve Uygulanan Politikalar. Journal of Academic Value Studies, 7(4), 429-437. } \\
\text { http://dx.doi.org/10.29228/javs.52032 }\end{array}$ \\
\hline
\end{tabular}

\footnotetext{
* Bu makale, 9-11 Haziran 2021 tarihlerinde Bişkek/Kırgızistan'da gerçekleştirilen 2. Uluslararası İktisadi ve İdari Bilimler Kongresi'nde sözlü olarak sunulan özet bildirinin genişletilmiş halidir.

${ }^{* *}$ E-mail address: aybukekaya.cu@gmail.com
} 


\section{Giriş}

Türkiye'de tarım sektörü, üretim ve tüketim bakımından ülke ekonomisine önemli katkılar sunmaktadır. Tarımdan elde edilen ürünler nihai ürün olarak değerlendirilebildiği gibi, sanayi sektörüne de hammadde sağlamaktadır. Şeker ve şeker pancarı yetiştiriciliği bu kapsamda yer alan en önemli sektörlerden biridir. Ayrıca şeker sektörü hem devlet müdahaleleri hem de uluslararası ticaret bakımından dikkat çekmektedir.

Beslenme açısından büyük öneme sahip olan şeker, insanların vücut fonksiyonlarını yerine getirmede gerekli yüksek kalorili bir besindir. Besin değerinin yanı sıra ekonomik katkılarıyla da öne çıkan şeker sektörü istihdam, üretim, ticaret gibi birçok konuda stratejik bir öneme sahiptir.

Şeker, temel gıda maddeleri arasında yer alan bir üründür. 18. yüzyılın sonuna kadar sadece şeker kamışından üretilirken, Avrupa'da yeni bir hammadde olarak şeker pancarı tarımı ve şeker pancarından şeker elde edilmeye başlanması 19. yüzyılda gerçekleşmiştir (Şentürk, 2020). Şekerpancarından elde edilen şeker, şekerkamışına göre \%25 daha fazla şeker içermektedir (Keskin, 2003). Pancardan üretilen şeker, kamış şekerine göre daha yüksek maliyetli olduğundan, pancar şekeri üretimi ile birlikte uygulanan politikalar da değişiklik göstermiştir. Pancar üretimi ve ticaretine yönelik farklı devlet müdahaleleri ile şeker sektörü desteklenmeye başlamıştır. Günümüzde şekerin, sürekli korunan ve desteklenen bir ürün olmasının temeli, pancardan şeker üretiminin başladığı 19. yüzyıla kadar dayanmaktadır. Dünya Ticaret Örgütü içinde yer alan ve AB ile üyelik müzakereleri yürüten Türkiye'de şeker sektörü, uluslararası pazarlara açıırken, $A B^{\prime}$ ye uyum çerçevesinde üzerinde durulması gereken sektörlerden biridir. Bu sebeple şeker sektörü dünyada olduğu gibi Türkiye'de de üretici ve tüketici bakımından değerlendirilmektedir (Kaya, 2015). Şeker, birçok ülke için gıda güvencesi, istihdam gibi pek çok sosyoekonomik konular nedeniyle dış piyasalarda korumacı politikalarla desteklenmiş ve liberal eğilimlerden en az etkilenen ürünlerden biri olmuştur. (Karabulut ve Topak, 2007; Eştürk, 2018).

Türkiye sahip olduğu iklim ve toprak yapısı itibariyle şeker pancarı yetiştiriciliğine elverişli bir bölgedir. Üretilen şekerin tamamı şeker pancarından elde edilmektedir. Dünya şeker pancarı üretiminde önemli bir paya sahip olan Türkiye, son yıllarda yaklaşık 3 milyon ton üretim miktarı ile dünya şeker üretiminde ilk sıralarda yer almaktadır. Şeker pancarı tarımı sosyo-ekonomik katkılarıyla Türkiye tarımında ve ekonomisinde önemli bir yere sahiptir (Şentürk, 2020). Ayrıca işlenmesi ile birlikte hayvancılıkta (küspe, melas) ve içki sanayisine de katkı sağlamaktadır (Eştürk, 2018). Hayvan beslenmesinde kullanılan melasın içeriğinde \% 50 oranında şeker bulunmaktadır. Etil alkol üretiminde fermantasyon hammaddesi olarak kullanılabildiği gibi, hayvan yemi, direk damıtılan içkilerde, içilemeyen kalitede endüstriyel tüketim ve ilaç sanayiinde, sirke, hamur mayası, yemlik mayada, briket kömür imalinde, inşaat harçlarında ve kozmetik sanayiinde kullanım alanı bulunmaktadır (Altunbay ve ark.,2016). Tüm dünyada desteklenen ve korunan sektörler arasında yer alan pancar tarımı ve pancar şekerinin sağladığı katkılar (istihdam, tarım ve hayvancılık, ilaç ve kimyasal üretimi, biyoyakıt vb.) ülke ekonomisine doğrudan etki yaptığı gibi; kırdan kente göçün engellenmesi ve çevreci olması gibi sosyal faydalara da sahiptir (Erdinç, 2018).

Tarıma dayalı sanayi işletmeleri arasında bulunan şeker fabrikaları ülke ekonomisinde önemli bir yere sahiptir. Türkiye'de üreticilerin modern tarım hakkında bilinçlendirilmesinde, yan ürünleriyle hayvancılığın gelişmesine katkı sunan, şeker pancarı tarımı, şeker fabrikalarına ham madde üretmektedir. Şeker, stratejik öneme sahip olan bir üründür. Türkiye'de Cumhuriyet'ten önce ithalat yoluyla karşılanırken, bugün tüketilen şekerin tamamına yakını ülke içinde üretilmektedir (Anonim, 2015).

Türkiye'de şeker sektörü içinde; 33 pancar şekeri fabrikasının kurulu olan üretim kapasitesi yaklaşık 3,5 milyon ton/yıl olup, "Şeker Kanunu" kapsamında kota tahsisi yapılan 5 şirkete ait 5 fabrikanın toplam nişasta bazlı şeker üretim kapasitesi 1 milyon 53 bin ton/yıl olarak belirlenmiştir. Ayrıca kota hakkı bulunmayan ve kota tahsisi olmayan, sadece yurt dışına ihraç edilmek için nişasta bazlı şeker üretim faaliyetinde bulunabilen 5 şirkete ait toplam nişasta bazlı şeker üretim kapasitesi ise 350 bin ton/yıldır. Türkiye'de tümü özel sektöre ait olmak üzere kota tahsis edilen 5 şirkete ait, 5 nişasta bazı ı̧eker fabrikası faaliyette bulunmaktadır. Ayrıca A kotası tahsisi bulunmayan 5 adet fabrika da faaliyet göstermekte olup, bu fabrikalarda üretilen nişasta bazlı şeker $C$ şekeri kapsamında ihraç edilebildiği gibi, ihraç ürünlerde kullanılmaktadır (TOB, 2021).

Türkşeker, 2000 yılında özelleştirme kapsamına 2007 yılında ise özelleştirme programına alınmış olmasına rağmen, bu süreçte satışının bir türlü gerçekleşememiş olması bu özelleştirme uygulamasının amaç ve yönteminin yeniden değerlendirilme ihtiyacı doğurmuştur. Özelleştirme kapsamında serbest piyasa ekonomisinin güçlendirilmesi, kamuya finansman katkısı ve yabancı sermayeyi teşvik etmek ve adil gelir dağılımı üzerinde durulmuştur. Ancak kar amaçlı yapılan bu uygulama temelde kapasite kullanım oranlarının artırımasıyla ilgilidir (Arslantürk, 2015). 
Şeker dünyada devlet müdahalesinin en fazla uygulandığı ürünlerden biridir. Bu kapsamda uygulanan üretim kotaları, tarife kotaları, yüksek korumalar ve tercihli ticaret anlaşmaları nedeniyle dünya serbest ticareti sınırlandırımaktadır. Son yıllarda yaşanan gelişmeler, şekerin diğer tarımsal mallar ve enerji piyasalarıyla etkileşimine neden olmuştur. Özellikle mısırdan elde edilen nişasta bazlı şekerin, şeker pancarı ve şeker kamışından üretilen şekerle rekabeti artmıştır. Ayrıca etanolün yakıt yerine kullanılmasıyla birlikte petrol ve şeker fiyatları birbiriyle bağlantılı hale gelmiştir (Anonim, 2008).

Dünyada uygulanan politikalara uyum sağlayabilmek, Türkiye'deki tarım politikalarına yön vermek amacıyla köklü değişiklikler yapılmaktadır. Şeker pancarı ise, bu değişikliklerden en fazla etkilenen tarım ürünüdür. Dünya Ticaret Örgütü ve Avrupa Birliği aracılığıyla güncel politikaların geliştirilmesi sağlanırken, Türkiye de bu süreçte yeni politikalara uyum göstermeye çalışmaktadır (Kaya, 2015).

Bu çalışmanın amacı, gündemden düşmeyen kamu şeker fabrikalarının özelleştirilmesi, dünya ve Türkiye'de şeker üretimi, ticareti ve şeker piyasasındaki gelişmeleri değerlendirmektir.

\section{Materyal ve Yöntem}

Bu çalışmada, Türkiye'de şeker üretimi ve piyasası, şeker fabrikalarının özelleştirilmesi ve uygulanan politikalar değerlendirilmiştir. Bu amaçla şeker sektörünün tarihsel gelişimi, şeker piyasasındaki gelişmeler, dış ticareti, özelleştirmeler ve sektörün dünyadaki mevcut durumu incelenmiştir. Bu kapsamda Tarım ve Orman Bakanlığı Tarımsal Ekonomi ve Politika Geliştirme Enstitüsü tarafından hazırlanan Türkiye şeker fabrikaları sektör raporu incelenmiştir. Ayrıca TÜIKK, FAO gibi istatistik kurumlarına ait veri tabanları kullanılmış olup, yapılan ulusal ve uluslararası çalışmalardan da yararlanılmıştır.

Araştırmada, dünyadaki şeker ve şeker kamışı üretimi, tüketimi, şeker ihracatında ve ithalatında yer alan ülkeler, şeker fiyatları, şekerin kullanım alanları ve uygulanan kotalar incelenmiş olup, $A B$ ve dünya şeker piyasaları çeşitli açılardan değerlendirilmiştir.

\section{Bulgular}

Farkıı kullanım alanlarına sahip şeker son yıllarda üretim, tüketim, dış ticaret rakamları bakımından artış göstermiş̧ir. Yıllar itibariyle dünya şeker verilerinde dalgalanmalar görülmekle birlikte sektörel bir gelişim söz konusudur. Dünya şeker üretimi ve tüketimi son 10 yılda yaklaşık 20 milyon ton artı̧̧ göstermiştir. Ithalat ve ihracat miktarlarının da son 10 yılda yaklaşık 7 milyon ton olarak gerçekleştiği görülmektedir. Stoklama imkanı bulunan şeker, yıllar itibariyle arz açığı ve arz fazlası şeklinde değişiklik göstermiştir (Tablo 1).

Tablo 1. Dünya şeker dengesine ilişkin değerler (milyon ton, 2018)

\begin{tabular}{|c|c|c|c|c|c|c|}
\hline YII & Üretim & Tüketim & İthalat & İhracat & Stok & $\begin{array}{r}\text { Arz } \\
\text { (fazla/açık) }\end{array}$ \\
\hline $2010 / 11$ & 156.2 & 153.1 & 53.9 & 53.9 & 67.9 & 3.0 \\
\hline $2015 / 16$ & 163.8 & 170.3 & 66.3 & 66.3 & 87.5 & -6.5 \\
\hline $2016 / 17$ & 169.1 & 172.2 & 65.0 & 64.9 & 84.7 & -3.1 \\
\hline 2017/18 & 179.8 & 171.2 & 62.6 & 62.4 & 93.6 & 8.6 \\
\hline 2018/19 & 174.0 & 170.7 & 57.5 & 57.5 & 96.7 & 3.4 \\
\hline $2019 / 20$ & 169.6 & 169.7 & 60.5 & 60.8 & 96.3 & -0.1 \\
\hline $2020 / 21 *$ & 173.5 & 174.2 & 60.3 & 60.2 & 95.7 & -0.7 \\
\hline
\end{tabular}

Kaynak: ŞDB, USDA, $2020(*) T a h m i n$

Dünya şeker üretimi son 10 yılda \%10'un üzerinde artış gösterirken, dünya şeker tüketimi \%13'ün üzerinde bir artış göstermiştir (Şekil 1). Bu durumun artan nüfus, şekerin farklı kullanım alanlarında değerlendirilmesi ve teknolojik gelişmeler ile ilişkili olduğu düşünülmektedir. 
Şekil 1. Dünya şeker dengesi (\%)

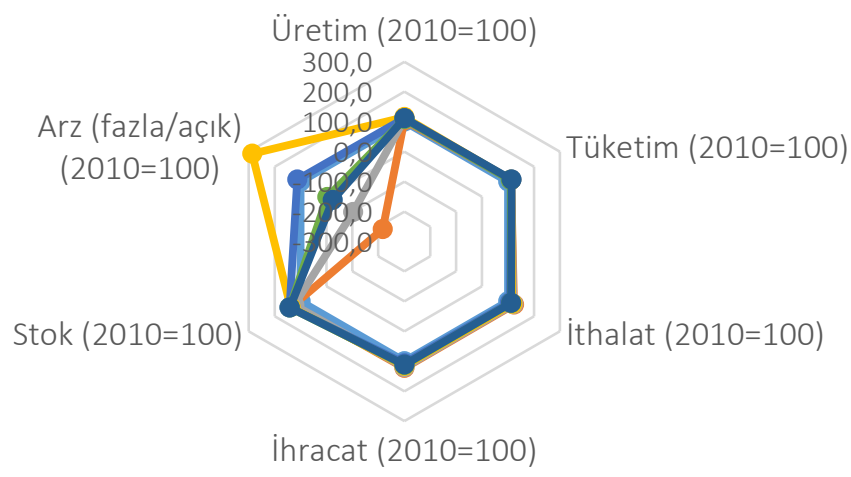

$-2010 / 11-2015 / 16-2016 / 17 \multimap 2017 / 18$
$-2018 / 19-2019 / 20 \longrightarrow 2020 / 21$

Dünya şeker pancarında Rusya, Fransa, ABD, Almanya ve Türkiye önde gelen ülkelerdir. Toplam şeker pancarı ekim alanı yaklaşık 5 milyon hektar olup, üretim miktarı yaklaşık 275 milyon tondur. Şeker pancarı üretiminde 5. sırada yer alan Türkiye'nin 2018 yılında 307.067 ha pancar ekim alanı ve yaklaşık 19 milyon ton üretim miktarı bulunmaktadır. Dünya şeker pancarı verimi ortalama $5.716 \mathrm{~kg} / \mathrm{da}$ olarak belirlenirken, Türkiye' nin şeker pancarı verimi $6.155 \mathrm{~kg} / \mathrm{da}$ 'dır. Bu değerler Türkiye'nin şeker pancarı verim ortalamasının, dünya ortalamasından \%7 daha fazla olduğunu göstermektedir (Tablo 2).

Tablo 2. Şeker pancarı üreten ülkeler (2018)

\begin{tabular}{|c|c|c|c|c|c|c|}
\hline Ülke & $\begin{array}{r}\text { Ekim alanı } \\
\text { (ha) }\end{array}$ & $\begin{array}{r}\text { İndeks } \\
(\text { Türkiye }=100 \text { ) }\end{array}$ & $\begin{array}{r}\text { Üretim } \\
\text { (ton) }\end{array}$ & $\begin{array}{r}\text { İndeks } \\
\text { (Türkiye=100) }\end{array}$ & $\begin{array}{l}\text { Verim } \\
\text { (kg/ha) }\end{array}$ & $\begin{array}{r}\text { İndeks } \\
\text { (Türkiye }=100 \text { ) }\end{array}$ \\
\hline Rusya & 1.105 .339 & 360.0 & 42.065 .957 & 222.6 & 38.057 & 61.8 \\
\hline Fransa & 485.251 & 158.0 & 39.579 .925 & 209.4 & 81.565 & 132.5 \\
\hline$A B D$ & 443.293 & 144.4 & 30.068 .647 & 159.1 & 67.830 & 110.2 \\
\hline Almanya & 413.900 & 134.8 & 26.191 .400 & 138.6 & 63.279 & 102.8 \\
\hline Türkiye & 307.067 & 100.0 & 18.900 .000 & 100.0 & 61.550 & 100.0 \\
\hline Polonya & 238.920 & 77.8 & 14.302 .911 & 75.7 & 59.864 & 97.3 \\
\hline Ukrayna & 274.700 & 89.5 & 13.967 .700 & 73.9 & 50.847 & 82.6 \\
\hline Çin & 216.130 & 70.4 & 12.077 .618 & 63.9 & 55.881 & 90.8 \\
\hline Misır & 219.087 & 71.3 & 11.222 .720 & 59.4 & 51.225 & 83.2 \\
\hline İngiltere & 114.200 & 37.2 & 7.620 .000 & 40.3 & 66.725 & 108.4 \\
\hline Diğer & 991.602 & 322.9 & 58.889 .428 & 311.6 & 59.682 & 97.0 \\
\hline Dünya & 4.809 .489 & 1566.3 & 274.886 .306 & 1454.4 & 57.155 & 92.9 \\
\hline
\end{tabular}

Kaynak: FAO, 2020

Şeker pancarı yetiştiriciliği verim ve kalite bakımından da ülkelere göre farklılık göstermektedir. Özellikle ülkelerin dünyadaki konumu, iklim ve toprak yapısı gibi faktörler verim ve kalite üzerinde etkili olmaktadır. Ayrıca; yetiştiricilik kapsamında toprak hazırlığı, gübreleme, ekim, bakım, zirai mücadele, sulama, hasat ve silolamaya kadar tüm işlemler bu durumu etkileyen diğer faktörler arasındadır.

Dünya şeker üretiminde yıllar itibariyle dalgalanmalar görülse de; Brezilya, Hindistan, AB, Tayland gibi ülkeler şeker üretiminde ilk sıralarda yer almaktadır. Dünya'da her yıl ortalama 175 milyon ton civarında şeker üretimi gerçekleşmektedir. Dünya şeker tüketiminde ise Hindistan, AB ve Çin gibi ülkeler önde gelen ülkeler arasındadır (Tablo 3). 
Tablo 3. Dünya'da en fazla şeker üreten/tüketen ülkeler ve Türkiye (milyon ton/BŞE)

\begin{tabular}{|c|c|c|c|c|c|c|c|}
\hline Üretici ülke & 2017 & 2018 & 2019 & $2020^{*}$ & Tüketici ülke & 2019 & $\%$ \\
\hline Brezilya & 39.2 & 38.9 & 29.5 & 29.9 & Hindistan & 27.0 & 15.8 \\
\hline Hindistan & 22.2 & 34.3 & 34.3 & 28.9 & $A B$ & 18.3 & 10.8 \\
\hline$A B$ & 18.3 & 20.9 & 17.9 & 17.0 & Çin & 15.4 & 9.1 \\
\hline Tayland & 10.0 & 14.7 & 14.5 & 8.2 & $A B D$ & 11.1 & 6.6 \\
\hline Çin & 9.3 & 10.3 & 10.7 & 10.4 & Brezilya & 10.7 & 6.2 \\
\hline$A B D$ & 8.1 & 8.4 & 8.1 & 7.4 & Endonezya & 7.4 & 4.3 \\
\hline Meksika & 6.3 & 6.3 & 6.8 & 5.6 & Rusya & 6.1 & 3.5 \\
\hline Rusya & 6.2 & 6.5 & 6.0 & 7.8 & Pakistan & 5.6 & 3.4 \\
\hline Pakistan & 6.8 & 7.2 & 5.2 & 5.2 & Meksika & 4.3 & 2.5 \\
\hline Türkiye & 2.5 & 2.5 & 2.7 & 2.7 & Türkiye & 3.0 & 1.9 \\
\hline Diğer & 45.1 & 44.2 & 43.6 & 42.4 & Diğer & 58.0 & 34.1 \\
\hline Dünya & 174 & 194.2 & 179.3 & 165.5 & Dünya & 170.2 & 100.0 \\
\hline
\end{tabular}

Kaynak: USDA, 2020

Türkiye şeker üretiminde kendine yeterli ülkeler arasındadır. Ancak bazı yıllarda ithalat yapmak durumunda kalmıştır. 1990'lı yıllardan itibaren uygulanan devlet müdahaleleri ve yüksek desteklemelerle şeker pancarında önemli stoklar oluşmaya başlamıştır (Konyalı ve Gaytancıoğlu, 2006). Uluslararası ticarete konu olan şekerin, ihracat ve ithalat gibi dış ticaret göstergeleri Tablo 4'te verilmiştir. Brezilya yaklaşık 20 milyon ton şeker ihracatı ile dünyada birinci sıradadır. Tayland, Hindistan ve Avustralya gibi ülkeler dünya şeker ihracatında söz sahibi iken; Endonezya, Çin ve ABD gibi ülkeler dünya şeker ithalatında öne çıkan ülkelerdir (Tablo 4). Dünya şeker ihracatının büyük çoğunluğunu kamış şekerinden elde edilen şeker oluşturmaktadır.

Şeker ticareti dünya borsası fiyatlarına göre belirlenmektedir. Ham şeker (New York No:11) New York borsasına göre belirlenirken, beyaz şeker (Liffe No:5) Londra borsasına göre belirlenmektedir. Türkşeker'in hazırladığı rapora göre; 2019 yılında beyaz şeker 333\$/ton, ham şeker 272\$/ton olarak belirlenmiştir. Kamış şekerinden elde edilen şekerin fiyatı, pancar şekerine göre daha düşük olduğundan dünya piyasalarında rekabet gücü yüksektir. Küresel rekabet ortamında rekabet avantajı, üstünlük sağlama stratejisidir (Sümer ve Yanık, 2021).

Tablo 4. Dünya şeker dış ticareti (2019/2020, milyon ton, BŞE)

\begin{tabular}{lrlr}
\hline Ülke & Ihracat Ülke & İthalat \\
\hline Brezilya & 19.3 Endonezya & 4.8 \\
Tayland & 7.0 Çin & 4.4 \\
Hindistan & 5.8 ABD & 3.7 \\
Avustralya & 3.6 Cezayir & 2.5 \\
Guatemala & 1.9 Bangladeş & 2.3 \\
Rusya & 1.6 AB & 2.1 \\
Güney Afrika & 1.5 Malezya & 2.0 \\
Meksika & 1.3 Güney Kore & 1.9 \\
AB & 1.2 Nijerya & 1.9 \\
Kolombiya & 0.8 Suudi Arabistan & 1.4 \\
\hline
\end{tabular}

Kaynak: USDA, 2020

Dünya şeker fiyatları genel olarak arz ve talebe göre şekillenirken; talep ve stoklar üzerinde spekülasyonlar, enerji ve emtia fiyatları, döviz, faiz, dış ticaret politikaları, enflasyon, politik ve finansal etkiler, ülkelerin ekonomik yapısı gibi birçok faktör etkili olmaktadır (Şentürk, 2020).

Şeker, pancar ve kamıştan elde edilebildiği gibi; mısır, buğday ve patates gibi nişasta kökenli ürünlerden de üretilebilmektedir. Dünya şeker sektörü 2020 yılı raporuna göre; nişasta bazlı şeker üreten ülkeler arasında ilk sırada ABD, Çin ve Japonya gibi ülkeler gelmektedir. Dünya genelinde 2019 yılında toplam 19 milyon ton civarında yüksek 
fruktozlu mısır şurubu üretimi gerçekleştirilirken, Türkiye'de ise fruktozlu mısır şurubunun 450 bin ton olduğu belirlenmiştir.

Türkiye şeker ihtiyacı Cumhuriyet Dönemi'ne kadar ithalat yoluyla karşılanırken, Cumhuriyet ile birlikte tüketilen şekerin neredeyse hepsi yurtiçinde üretilmiştir. Kendine yeterlilik seviyesinin arttırılmasına yönelik düzenlenen politikalar doğrultusunda uygulanan devlet müdahaleleri ve teşvikler sayesinde ülke stokları da zamanla artış göstermiştir. Ancak ihtiyacın üzerinde artan stoklar kota uygulamalarıyla sınırlandırılarak, şeker pancarı yetiştiriciliğine müdahaleler yapılmıştır. Türkiye'de şeker ihtiyacına yönelik uygulanan kotalar Tablo 5’te verilmiştir.

Tablo 5. Pancar şekeri ve NBŞ kotaları (bin ton)

YII

$2010 / 11$

$2011 / 12$

$2012 / 13$

$2013 / 14$

$2014 / 15$

$2015 / 16$

2016/17

$2017 / 18$

$2018 / 19$

$2019 / 20$

2020/21

* NBŞ kotası \% 50 oranında düşürülmüștür.

**NBŞ kotası \% 50 oranında düşürülmüştür.

Kaynak: Türkşeker, 2020 (Şentürk, 2020 tarafından düzenlenmiştir).

\section{NBŞ Kotası (A) NBŞ Kota Artışı (\%)* Toplam A Kotası}

$\begin{array}{lccc}2.200 & 244 & 50 & 2.566 \\ 2.200 & 244 & 35 & 2.529 \\ 2.200 & 244 & 38 & 2.537 \\ 2.200 & 244 & 25 & 2.505 \\ 2.250 & 250 & 30 & 2.575 \\ 2.250 & 250 & 25 & 2.563 \\ 2.385 & 265 & 0 & 2.650 \\ 2.537 & 267 & -50 & 2.670 \\ 2.565 & 135^{*} & - & 2.700 \\ 2.633 & 67,5^{* *} & - & 2.700 \\ 2.737 & 67,5 & - & 2.700\end{array}$

Türkiye'de şeker pancarı destekleme politikaları kapsamında; 19.04.2001 tarihinde yürürlüğe giren 4634 sayılı Şeker Kanunu ile şeker fabrikalarının piyasa paylarının kotalara bağlanması ve iç piyasada sanayinin rekabet edilebilir hale getirilerek, devlet müdahalesinin etkisi azaltılmaya çalışılmıştır. Türkiye'de şeker pancarı yetiştiriciliğinde uygulanan destek ödemeleri yıllar itibariyle değişiklik göstermiştir. Şeker pancarı üretiminde fark ödemesi bulunmazken, organik tarım desteğinde şeker pancarı, 2015 yılında tarla bitkileri kapsamında 10 Ł/da, 2019 yılına kadar 4. kategoride diğer ürünler başlığında $10 \mathrm{TL} / \mathrm{da}, 2019$ yılında ise 2.kategoride değerlendirilerek, bireysel başvuruda 40 ‡/da, üretici grubunda 20 Ł/da ürün sertifikası desteklenmiştir. Son iki yılda önceki yıllara göre destekler arasında en fazla değişim mazotta görülmüştür. Pancar yetiştiriciliğinde dekara verilen mazot desteği, 2015 yılına kıyasla 2019 yılında \% 47 artış göstermiştir. 2015 yılında $1 \mathrm{~kg}$ şeker pancarı ile alınabilecek gübre miktarı 0,13 kg, mazot 0,04lt, tohum ise 0,002 kg olarak belirlenmiştir. 2019 yılı ortalamasına göre ise $1 \mathrm{~kg}$ şeker pancarı ile alınabilecek gübre miktarı 0,12kg, mazot 0,03 It, tohum ise 0,001 kg'dir (Anonim, 2020). Birim alana kullanılan gübre ve sulama suyu miktarı fazla olup, özellikle toprak hazırlığı ve hasat harman işlerinde insan ve makine işgücünün yoğun kullanımı üretim maliyetlerini arttırırken, verimde olumsuz etkilere sebep olmaktadır (Topçu ve ark., 2012).

Şeker pancarı, Türkiye'nin Ege, Akdeniz sahili, Doğu Karadeniz ve Güneydoğu Anadolu Bölgesi dışında tüm bölgelerde yetiştirilmektedir. Uygulanan politikalar doğrultusunda son 10 yılda Türkiye'nin şeker pancarı ekim alanı ve verim değerleri pek değişmemiştir. Buna bağlı olarak ortaya çıkan üretim miktarı da 18 milyon ton civarında seyretmektedir. Türkiye'de 2018 yılında şeker pancarı üretimi 1.350'nin üzerinde lokasyonda gerçekleştirilmiştir. Türkiye'nin yaklaşı 1 milyon da şeker pancarı ekim alanı bulunmaktadır. Bu alandan her yıl ortalama 6 ton/da verim elde edilmektedir. Türkiye şeker pancarı üretiminde Konya, Eskişehir, Ankara, Karaman ve Yozgat önde gelen iller olarak belirlenmiştir. Illere göre şeker pancarına ait veriler Tablo 6'da verilmiştir. 
Tablo 6. İllere göre şeker pancarı verileri (2018)

\begin{tabular}{lrrrr|lr} 
Illler & $\begin{array}{c}\text { Lokasyon } \\
\text { (Köy/Mahalle) }\end{array}$ & $\begin{array}{c}\text { Ekim alanı } \\
\text { (da) }\end{array}$ & $\begin{array}{c}\text { Bedeli ödenen } \\
\text { (ton) }\end{array}$ & $\begin{array}{c}\text { Verim } \\
\text { (ton/da) }\end{array}$ & 2019 (bin ton) \\
\hline Konya & 168 & 207.558 & 1.453 .208 & 7 & Üretim & 2.536 \\
Eskişehir & 169 & 178.277 & 1.022 .156 & 5,76 & Yurtiçi satış (A kotası) & 2.468 \\
Ankara & 110 & 86.198 & 537.534 & 6,24 & Yurtdısı Satış (C Şekeri) \\
Karaman & 40 & 77.017 & 554.379 & 7,2 & \\
Yozgat & 126 & 62.690 & 352.241 & 5,66 & \\
Kastamonu & 102 & 35.590 & 167.915 & 4,75 & \\
Denizli & 57 & 29.448 & 142.512 & 4,84 & \\
Bursa & 63 & 26.682 & 196.741 & 7,74 & \\
Burdur & 48 & 25.798 & 131.448 & 5,1 & \\
Ağrı & 33 & 22.544 & 84.819 & 3,76 & \\
\cline { 1 - 3 } Türkiye & 1.354 & 965.869 & 5.780 .670 & 6,03 & \\
\hline
\end{tabular}

Kaynak: Türkşeker, 2020; ŞDB, 2020

Türkiye'nin son 10 yılda pancar şeker ihracatı \%50'nin üzerinde azalma göstermiştir. Nişasta bazlı şeker ihracatında ise 3 katının üzerinde ciddi bir artış söz konusudur. 2019 yılında ise 169 bin ton pancar şekeri ithal edilirken, 26 bin ton nişasta bazlı şeker ithalatı gerçekleşmiştir. Yine aynı yıl 30 bin tonun üzerinde pancar şeker ihracatı gerçekleşmiş olup, 268 bin ton nişasta bazlı şekerin ihraç edilerek dış ticarete konu olmuştur (Anonim, 2020).

Şeker pancarı satış fiyatları son 10 yılda ciddi bir artış göstermiştir. 2010 yılında \%16 polar şeker içeren şeker pancarı 119 Ł/ton iken, 2020 yılında 336 Ł/ton olarak belirlenmiştir. 2010 yılı baz alınarak şeker pancarı fiyatının yıllar itibariyle yüzde değişimi basit indeks yöntemiyle Şekil 2'de verilmiştir.

\section{Şekil 2. Yıllar itibariyle şeker pancarı satış fiyatı TL/ton $(2010=100)$}

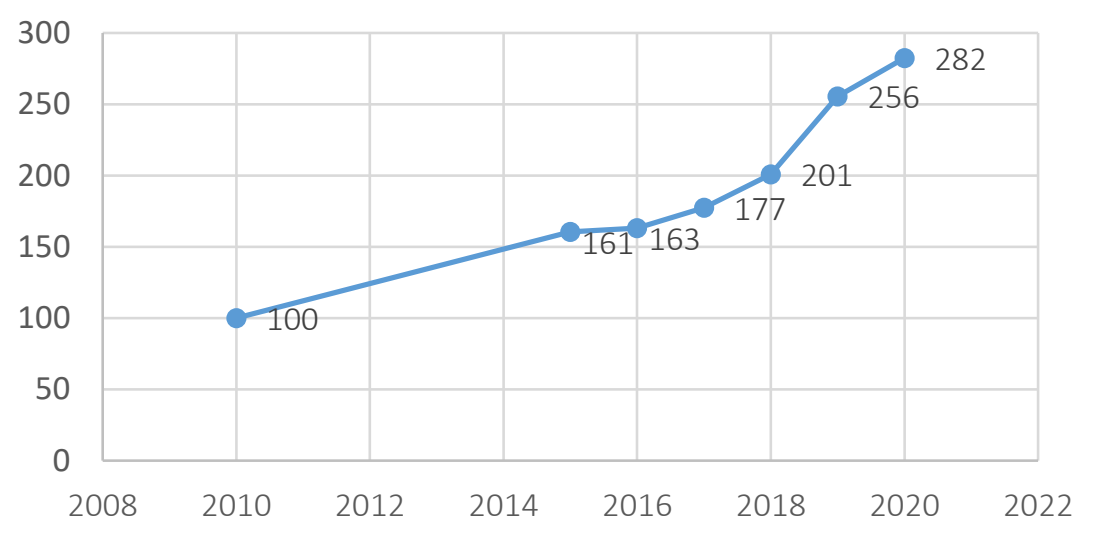

Nişasta bazlı şekerler, tatlandırıcı olarak şekerli ürünlerin (reçel, içecek, şekerleme vb.) üretiminde kullanılmaktadır. Şeker pancarından elde edilen şekere göre daha düşük maliyetle elde edilmesi satış fiyatları üzerinden de belli olmaktadır. Gıda sektöründe hammadde olarak kullanılan nişasta bazlı şeker (NBŞ) için de kota uygulanmaktadır. Türkiye'de şeker satış fiyatları ve NBŞ üretim ve satış kotası Tablo 7'de verilmiştir. 
Tablo 7. Şeker satış fiyatları

\begin{tabular}{|c|c|c|c|c|c|c|}
\hline \multirow[b]{2}{*}{ YII } & \multicolumn{2}{|c|}{ Pancar şekeri } & \multicolumn{2}{|c|}{ Nişasta bazlı şeker } & \multirow{2}{*}{\multicolumn{2}{|c|}{$\begin{array}{c}\text { NBŞ } \\
\text { üretim/satış } \\
\text { (bin ton) }\end{array}$}} \\
\hline & $\mathrm{TL} / \mathrm{kg}$ & $\begin{array}{r}\text { Yıllık } \\
\text { Değişim (\%) }\end{array}$ & $\mathrm{TL} / \mathrm{kg}$ & $\begin{array}{r}\text { Yıllık Değişim } \\
(\%)\end{array}$ & & \\
\hline $2011 / 12$ & 1,93 & 7,82 & 1,37 & 8,73 & Üretim & 488 \\
\hline $2012 / 13$ & 2,11 & 9,33 & 1,47 & 7,30 & Yurtiçi satış (A kotası) & 67 \\
\hline $2013 / 14$ & 2,33 & 10,43 & 1,57 & 6,80 & Yurtdışı satış (C şekeri) & 403 \\
\hline 2014/15 & 2,52 & 8,15 & 1,74 & 10,83 & & \\
\hline $2015 / 16$ & 2,70 & 7,14 & 1,87 & 7,47 & & \\
\hline 2016/17 & 2,66 & $-1,48$ & 1,92 & 2,67 & & \\
\hline $2017 / 18$ & 2,87 & 7,89 & 2,11 & 9,89 & & \\
\hline 2018/19 & 3,13 & 9,05 & 2,70 & 27,48 & & \\
\hline $2019 / 20$ & 3,57 & 14,05 & 3,30 & 22,67 & & \\
\hline
\end{tabular}

Kaynak: Türkşeker, ŞDB, 2020

\section{Sonuç ve Öneriler}

Türkiye şeker üretiminde önde gelen ülkeler arasındadır. Türkiye'nin şeker ihtiyacı şeker pancarından elde edilen beyaz şeker ve nişastadan üretilen glikoz ile karşılanmaktadır. Üretim ve dış ticaretiyle ön plana çıkan şeker, sanayi sektörü bakımından da önemlidir. Şeker, gıda sektörü başta olmak üzere ilaç, içecek, yem, yakıt vb. birçok alanda kullanımıyla ülke ekonomisine katkı sağlamaktadır. Bu alanda yaratılan katma değer ekonomik gelişme ve kalkınmayı desteklemektedir. Ancak; farklı kullanım alanlarına sahip ve stratejik bir olması nedeniyle dünya genelinde devlet müdahalesinin yoğun olduğu bir üründür. Son yıllarda artan nüfusun şeker ihtiyacının karşılanmasında şeker kamışının payı artmıştır. Dünyada şekerin yaklaşık $4 / 5^{\prime} i$ kamıştan, $1 / 5^{\prime} i$ ise pancardan üretilmektedir. Şeker üretiminde pancar ve kamış kullanımı üzerinde ülkelerin coğrafi konumu etkili olmaktadır. Şeker pancarı üretimindeki maliyetlerin yüksek olması, şeker kamışı veriminin daha yüksek olması ve üretimdeki kotalar, artan girdi maliyetleri dünya şeker üretimini sınırlamaktadır. Bu sebepler kamış şekerine olan talebi arttıırken, şeker pancarına olan talebi düşürmekte olup, dünya piyasalarında rekabet gücü üzerinde de etkili olmaktadır. Dünya şeker üretimine Brezilya ve Hindistan gibi ülkeler hakimken, dünya şeker tüketimine yine Hindistan, $A B$ ve Çin gibi ülkelerin ön plana çıktığı görülmektedir. Gelişen teknoloji ve sanayide kullanım alanının artmasıyla Türkiye'nin dünya şeker piyasaları üzerinde söz sahibi olduğu ve bu durumun gelecekte de süreceği öngörülmektedir. Sonuç olarak şekerin katma değeri yüksek olduğundan, Türkiye'de şeker üretimini teşvik edici politikaların varlığı üretim ve rekabet gücünü artıracaktır. Dolayısıyla şeker fabrikalarının devamlılı̆ının sağlanması ülke ekonomisini desteklemektedir. Türkiye' de üretilen şeker pancarının, hammadde olarak ihraç edilmesinden çok, şeker olarak pazarlanmasına önem verilmelidir. Ayrıca, üreticilerin bilinçlendirilmesine yönelik yayım faaliyetleri artırılmalıdır.

\section{Kaynaklar}

Altunbay, S.G., Kangal A. \& Gürel S. (2016). Şeker Pancarından Biyoetanol Üretimi, Tarla Bitkileri Merkez Araştırma Enstitüsü Dergisi, 2016, 25 (Özel sayı-2):334-339.

Arslantürk, Y. (2015). Özelleştirme Perspektifinden Türkşeker Analizi ve Yeni Politika Önerileri, Gazi Üniversitesi Sosyal Bilimler Enstitüsü Yüksek Lisans Tezi, Ankara.

Anonim (2020). Tarım Ürünleri Piyasaları-Şeker Pancarı, Tarım ve Orman Bakanlığı Tarımsal Ekonomi ve Politika Geliştirme Enstitüsü, Ocak 2020 (Ürün No: BÜ-20).

Anonim, (2008) Türkiye'de Tarım ve Gıda: Gelişmeler, Politikalar ve Öneriler, Bölüm 6, TÜsiAD Yayın No:2008-05/459, Sayfa 103 (Çakmak, E. katkılarıyla). 
Anonim, (2015). Şeker Pancarı ve Şeker Ürün Raporu, Gıda, Tarım Ve Hayvancılık Bakanlığı, Tarımsal Ekonomi ve Politika Geliştirme Enstitüsü, Tepge Yayın No: 271, Sayfa 8 (Tosun, F. katkılarıyla).

Erdinç, E. (2018). Türkiye'de Şeker Sanayinin Gelişimi ve Şeker Sanayinde İzlenen Politikalar, Anadolu Üniversitesi Sosyal Bilimler Dergisi, Cilt: 17, Sayı: 3, 9-26.

Eştürk, Ö. (2018). Türkiye'de şeker sektörünün önemi ve geleceği üzerine bir değerlendirme, Anadolu İktisat ve İşletme Dergisi, 2 (1), 67-81.

FAO, (2020). http://www.fao.org/faostat. Erişim tarihi:30.11.2020.

Karabulut, T. \& Topak, A. (2007). Şeker Sanayiinde Maliyet ve Verimlilik Analizi: Kamu ve Özel Sektör Karşılaştırması”, Selçuk Üniversitesi Sosyal Bilimler Meslek Yüksekokulu Dergisi, 10(1-2): 1-20.

Kaya, F. (2015). Küresel ve Bölgesel Şeker Politikalarının Türkiye Şeker Fabrikalarına Etkilerine Bir Örnek; Ağrı Şeker Fabrikası, İstanbul Üniversitesi Edebiyat Fakültesi Coğrafya Dergisi Sayı 31,41-61. (Elektronik) ISNN 1305-2128.

Keskin, G. (2003). Şeker ve tatlandırıcılar. Tarımsal Ekonomi Araştırma Enst. Bakış Dergisi, 2 (7): 15-23, Ankara.

Konyalı, S. \& Gaytancıoğlu, O. (2006), “Türkiye'de Şeker Pancarı'nda Uygulanan Tarım Politikaları",http://www.dunyagida.com.tr/haber/turkiyede-seker-pancarinda-uygulanan-tarim-politikalari/1789 (28.03.2018).

Sumer, S. \& Yanık, R. (2021). Gıda Işletmelerinde Üretim Reçetesinin Denetim Yönünden Ele Alınması. Journal of Academic Value Studies, 7(3), 368-374. http://dx.doi.org/10.29228/javs.51920.

Şentürk, Ö. (2020) Şeker Pancarı Ürün Raporu, Tarım ve Orman Bakanlığı, Tarımsal Ekonomi ve Politika Geliştirme Enstitüsü TEPGE YAYIN NO: 328, ISBN: 987-605-7599-57-5.

TOB, (2021). Tarım ve Orman Bakanlığı, Şeker Dairesi Başkanlığı, Erişim tarihi: 20.06.2021 Erişim linki: https://www.tarimorman.gov.tr/SDB/Menu/96/Turkiye-Seker-Sektorune-Iliskin-Sorular.

TOB, 2020. Tarım ve Orman Bakanlığı, Şeker Dairesi Başkanlığı, Dünya Şeker Sektörü Raporu, Ekim 2020.

Topçu, Y., Uzundumlu, A.S. \& Karadaş, K. (2012). Erzurum Ilinde Şeker Pancarı Üretim Maliyeti, Iğdır Üni. Fen Bilimleri Enst. Der. / Iğdır Univ. J. Inst. Sci. \& Tech. 2(2,Ek:A): 41-50.

Türkşeker, (2020). 2019 Sektör Raporu, Mayıs 2020.

USDA,2020. https://apps.fas.usda.gov/psdonline. Erişim Tarihi:30.11.2020. 